\title{
Gd-Catalyzed Photocycloaddition of Aryl Cyclopropyl Ketones to Alkenes
}

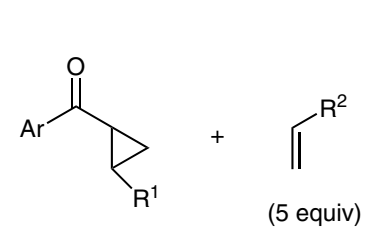

$$
\begin{gathered}
\mathrm{Ru}(\mathrm{bpy})_{3}\left(\mathrm{PF}_{6}\right)_{2}(2.5 \mathrm{~mol} \%) \\
\mathrm{Gd}(\mathrm{OTf})_{3}(10 \mathrm{~mol} \%) \\
\text { ligand }(20 \mathrm{~mol} \%) \\
\text { DIPEA (1 equiv) } \\
\hline \text { visible light } \\
\mathrm{MeCN}, 6-20 \mathrm{~h}
\end{gathered}
$$<smiles>[R7]C1C[C@@H]([R7])[C@H](C(=O)[AlH2])C1</smiles>

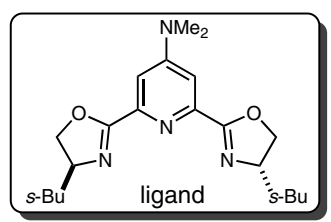

Selected examples:<smiles>CCCOC(=O)[C@@H]1C[C@@H](C(=O)c2ccccc2)[C@H](c2ccccc2)C1</smiles><smiles>COc1ccc(C2CCC[C@H]2C(=O)c2ccccc2)cc1</smiles><smiles>C=C(C)[C@@]1(C)C[C@@H](OC(C)(C)C)C[C@H]1C(=O)c1ccccc1</smiles>

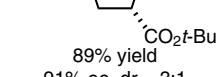
$91 \%$ ee, $\mathrm{dr}=3: 1$<smiles>CCOC[C@H]1C[C@@H](C(=O)c2cccnc2)[C@H](c2ccccc2)C1</smiles>
$" \mathrm{CO}_{2} t-\mathrm{Bu}$ $57 \%$ yield
$89 \%$ ee, $d r=2: 1$<smiles>[CH2]c1ccc(C2CCCC2C=O)cc1</smiles>

$" \mathrm{CO}_{2} t-\mathrm{Bu}$

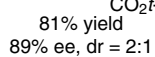<smiles>CC(=O)[C@@H]1C[C@@H](C(=O)c2ccccc2)[C@H](c2ccccc2)C1</smiles>

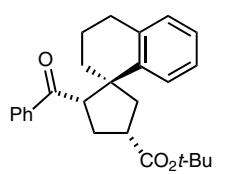

\section{Category}

Metal-Catalyzed Asymmetric

Synthesis and

Stereoselective

Reactions

\section{Key words}

cycloaddition

photoredox reaction

gadolinium

catalysis

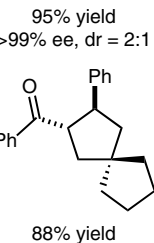

Proposed mechanism:

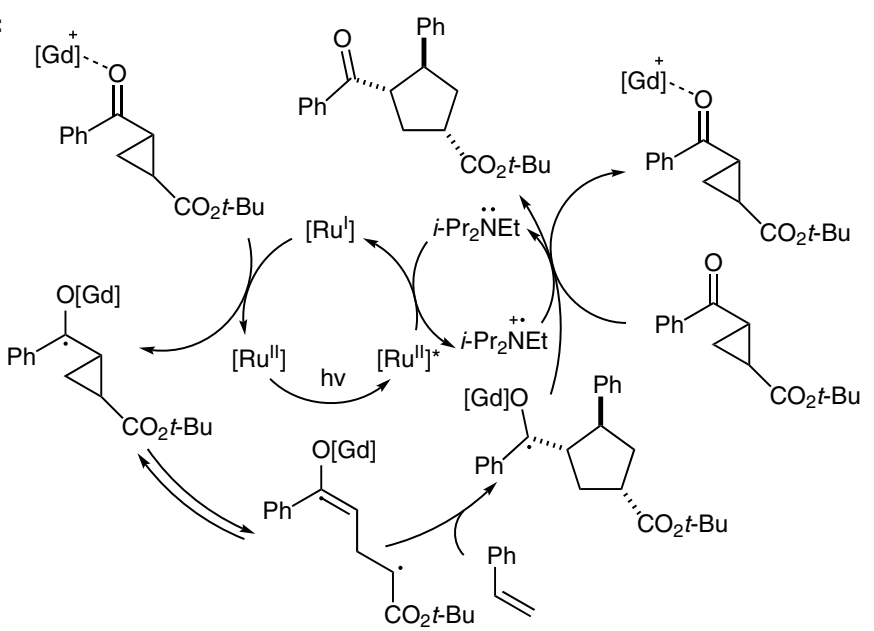

Significance: The authors report a gadoliniumcatalyzed asymmetric [3+2] photocycloaddition of aryl cyclopropyl ketones with alkenes. A variety of chiral cyclopentanes were obtained in high yields ( $\leq 95 \%$ ) and stereoselectivities (up to $>99 \%$ ee and dr up to $>20: 1$ ).
Comment: This result demonstrates that a combination of a chiral Lewis acid and photoredox catalysis offers a robust and potentially general approach to photochemical stereocontrol that is broadly applicable to the increasing number of powerful transformations achievable by using photoredox catalysis.

SYNFACTS Contributors: Hisashi Yamamoto, Masahiro Sai

Dol: 10.1055/s-0035-1562292; Reg-No.: H07516SF 